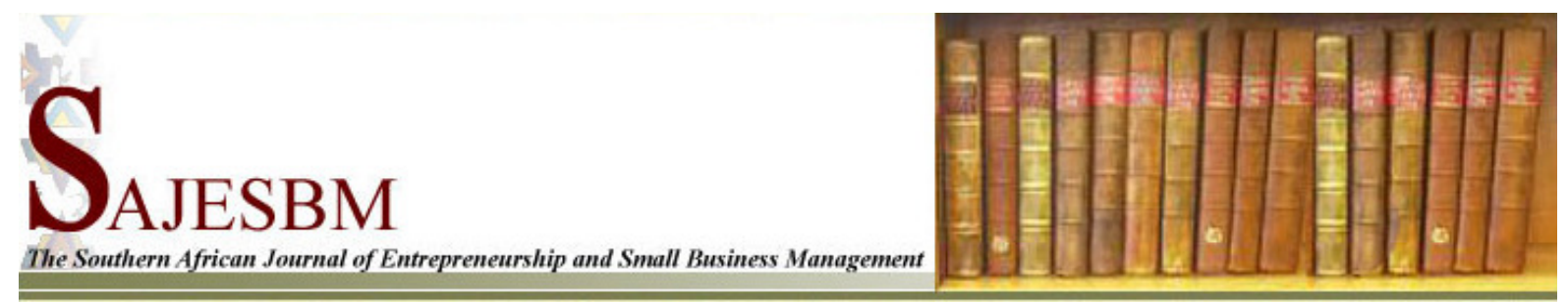

www.sajesbm.com

\title{
Development model for family business successions evaluation with a South African case study
}

Chris ADENDORF PhD

NMMU Business School

Fidelis EMUZE*

Central University of Technology, Free State

Bloemfontein, 9300, South Africa

\section{Graham WARD}

NMMU Business School

\author{
* To whom correspondence should be addressed \\ Private Bag X20539 \\ Central University of Technology, Free State, Bloemfontein, 9300, South Africa \\ Phone: 051507 3661, femuze@cut.ac.za
}

\begin{abstract}
Family businesses (FB) contribute between 45 and $90 \%$ to global gross domestic product (GDP). However, empirical research has raised the alarm pertaining to the need to prolong the longevity of such businesses. Findings indicate that within the next 5 years, over $50 \%$ of FB executives could retire from day to day running of such businesses. This highlights the significance of successful business successions. The dynamics around the succession process and the criteria influencing successful successions have thus engaged the attention of researchers. Therefore, the purpose of this study was to better understand the development of successors in FB. The study began with a literature survey through which a development model was identified. The study then went on to evaluate the model through an FB case study. The single qualitative case study was used to test whether the six (6) prepositions proposed in the model applied to the case that was studied. Through one-onone interviews and a qualitative data analysis, it was observed that the 6 prepositions were applicable to the FB. In other words, FB grappling with succession planning can be advised to endeavour to understand and take actions aligned with the prepositions.
\end{abstract}

Keywords: Family businesses, Small businesses, Shareholders, Succession 


\section{BACKGROUND}

A family business (FB) may be defined as "a business governed and / or managed with the intention to shape and pursue the vision of the business held by a dominant coalition controlled by members of the same family or a small number of families in a manner that is potentially sustainable across generations of the family or families" (Chua, Chrisman and Sharma, 1999). However, reports from the United States of America (USA) indicate that many founders of businesses that were started in the "baby-boom" period are reaching or are close to retirement age and are in need of successors (Cullen, 2005). Recent research conducted by Venter and Boshoff (2007) show that 30\% survive the second generation; with little more than $14 \%$ making it past the third generation. As a result, Landes (2006) refers to family firms that have succeeded to the third generation as "Dynasties" and he describes the achievement as "mammoth".

Walsh (2011) further observes that family business succession is the process of transitioning the management and the ownership of the business to the next generation of family members. The transition may also include family assets as part of the process. Family members typically play a controlling role in both the management succession as well as the ownership succession. As such, the effective integration and management of the family component will have a determining effect on the success of the succession process. FB succession typically involves the transfer of knowledge, control, power and management responsibilities from one generation to the next one (Santiago, 2000). A successful FB succession should seek to improve the profitability of the business and stakeholders (Bigliardi and Dormio, 2009). However, it should be noted that psychological factors could affect successions. Such factors are not limited to candidates' personal skills and experience outside the business, commitment to the family goals and the legitimacy of the successor as viewed through the eyes of the employees within the company (Poutziouris, Smyrnios, Klein, 2006). Nevertheless, succession planning in FB is reportedly a subject area that is under explored. In other to contribute to the debate and also considering the low success rate of FB successions, this study was embarked upon to:

- Assist FB with improving the success rate of successions, and

- Provide future researchers with additional criteria that may contribute to successful FB successions.

Thus, the overall research objective was underpinned by the need to analyse and verify Cater and Justis' (2009) proposed model entitled "Development of Successors from Followers to Leaders in Small Family Firms", in order to determine if the model prepositions could influence successions in FB.

\section{The Research Problem}

The main problem assumed for the study is the reported low success rate of FB successions. This low success rate has proliferated empirical studies related to FB so that the dynamics that may positively and / or negatively affect successful successions can be identified. It is notable that past findings agreed that the succession process should be planned well in advance as the transfer of knowledge and leadership skills are essential to the process (Cullen, 2008; Venter and Boshoff, 2007; Chua et al., 1999; Cater and Justis, 2009).

In order to solve the abovementioned main problem, Cater and Justis (2009) developed a model that proposed six dynamic prepositions that could influence the emergence of successors in FB. These prepositions include:

- A positive parent / child relationship between the founder or incumbent and the successor enhances the development of successor leadership; 
- The possession of a long-term orientation enhances successor leadership;

- The possession of the spirit of cooperation among successors enhances successor leadership;

- The thorough and rapid acquisition of company and industry knowledge enhances the development of successor leadership;

- Understanding the role of manager-builder in the family firm enhances the development of successor leadership, and

- Understanding one's orientation toward risk taking enhances one's development as a successor leader.

\section{REVIEW OF RELATED LITERATURE}

Venter and Boshoff (2007) suggest that the transfer of leadership is one of the biggest reasons $\mathrm{FB}$ fail to move from one generation to the next. A lack of a planned approach to succession and choice made by families over the ownership structure are often the reason for the failure of successions (Cullen, 2005; Venter and Boshoff, 2007; Chua et al., 1999; Farrington, 2009).

Banking moguls such as the Rothschild family found that by having "lots" of children, they have a better chance of business continuity (Landes, 2006). This was based on the premise that potential successors would emerge from the children.

Daniell (2008) notes that FB that have managed to trade beyond the third generation think long term and typically has the character and tenacity to ride out the bad times, and make the necessary adaptations for survival by implementing difficult decisions in order to ensure the survival of the business above other commercial considerations. However, family firms have complexities related to ownership and family conflicts (Schwass, 2008). According to Schwass (2008), due to these complexities, FB may adopt unconventional business models that will enable them to achieve greater success than their non-family owned counter parts. In brief, in as much as family members may be instrumental to business success, they may also have a negative effect on the performance of the business by inflicting the need for conflict resolution far too often (Schwass, 2008).

\section{Benefits of Family Businesses}

Chrisman, Chua and Sharma (2003) argue that it would be invaluable to research the relationship between family involvement and competitive advantage as this would allow the exploitation of the ability of family firms to enhance their economic performance. Grant (2007) observed that competitive advantage is evident in FB where there is typically more loyalty, passion and commitment than in non-family owned businesses because successors could strive to build on the legacy of their founders. Landes (2006) suggests that one of the greatest competitive advantages a company can have is the bloodline. Grant (2007) further argues that the value system of a family firm is passed down from generation to generation. This value system creates a work culture that continues into the personal lives of the members. Barney, Clark and Alvarez (2002) suggest that family bonds may even offer opportunities over and above non-family businesses due to family members' willingness to share information more readily.

Since successors tend to enjoy a longer period of grooming and preparation for succession, it can be argued that FB has an advantage over non-family owned businesses in this regard (Daniell, 2008). Colli (2003) suggests that in most cases, the preparation of the successor is handled within the family. Daniell (2008) finds that larger families often resort to a "family constitution", which sets out an approach and guide for members to abide by, thus 
minimising conflict and tabulating a success path for the business. The constitution defines the family, its identity, vision, values, mission and the rights and responsibilities of members. In addition, the constitution typically has checks and balances in place to curb the abuse of power (Daniell, 2008). Landes (2006) provides an example where Mayer Rothschild, a prominent banker, drew up a partnership agreement to guide the family before he died. The agreement provided clear rules for order, family behaviour and the succession of power, and it gave his descendants a code by which they could live by and protect their private and business lives. Mayer Rothschild made it clear that there would be no room in the FB for females or sons-in-law and furthermore, that his heir and descendants would only be allowed to marry Jewish wives (Landes, 2006).

\section{Pitfalls of Family Businesses}

Family firms suffer challenges not commonly found among non-family businesses because problems are carried over into the family (Schulze, Lubatkin and Dino, 2003). Grant (2007) mentions that between generations, personal goals of the members may differ. The difference thus requires clarifications to avoid harmful conflicts, which has the potential to destroy the business. As an illustration, excessive pressure that could lead to conflicts that hinder the development of the business may be placed on family members to succeed the family business (Bertrand and Schoar, 2006). The Gucci family is a prime example of a family business, which rose to great heights only to be brought into disarray through family member differences, lawsuits and other debilitating conflicts (Daniell, 2008). Another potential risk faced by FB is that of divorce (Daniell, 2008). This sensitive issue can range from insignificant to enormous depending on the couple involved, the nature of the divorce, the structure of the family wealth and the local laws involved (Daniell, 2008).

Research shows that the two most potentially harmful risks to the family firms are excessive shareholding and difficult sons-in-law (Daniell, 2008). Barney et al. (2002) believe that the need to maintain family ties reduces family members' ability to maintain other strong social ties, which may weaken their social networking skills. However, one of the most challenging areas is that of compensation. Grant (2007) argued that often funds are misused for personal goals at the detriment of the FB. Founders tend to be poor planners and find it difficult to share and articulate their vision to potential successors (Grant, 2007). Grant (2007) went on to say that the sooner the founder manages the "family element" effectively, the better the chances are that the FB will be transferred to the next generation.

\section{THE RESEARCH METHOD}

In accordance with Yin (2003), a prominent FB within Port Elizabeth, South Africa, was chosen as the case study. The business is part of a successful franchise chain that is concerned with the wholesale and retail sales of motor spare parts and accessories to mechanical shops and the general public. The firm opened for trading in 1995 with only one store. At the time of the investigation, the firm has grown to three stores. Under the successful leadership of the founder, a further franchise was acquired in 2001. In 2005 the two eldest brothers were instrumental in opening the last franchise. All the franchises operate in the Port Elizabeth area and each one is run separately by one of the brothers.

The family consisted of the parents and 4 siblings as indicated in Table 1 . The eldest sibling is female. She opted not to succeed the parents. The remaining siblings are males and each plays a significant role in the day to day running of the business. The founder and the 3 brothers individually own $25 \%$ stake in the FB. The founder participates in significant meetings that may affect the family business, but leaves the day-to-day decisions to the successors. The founder still draws an income from the business apart from the $25 \%$ shares that he maintains in the firm. 
Table 1 Respondents to the case study

\begin{tabular}{|l|l|l|c|l|c|}
\hline Title & Code & Description & Age & Sex & Ownership (\%) \\
\hline Founder & FF & Father & 61 & Male & 25.0 \\
\hline Founder & FM & Mother & 58 & Female & 0.0 \\
\hline Sibling & S & Sister & 37 & Female & 0.0 \\
\hline Successor sibling & SSE & Eldest brother & 34 & Male & 25.0 \\
\hline Successor sibling & SSS & Second brother & 33 & Male & 25.0 \\
\hline Successor sibling & SST & Third brother & 29 & Male & 25.0 \\
\hline
\end{tabular}

The data collected from the interviews were analysed and verified against the six prepositions in Cater and Justis (2009) successor development model. The questionnaire was designed to collect data to support or negate the prepositions. The questions were semi-structured in nature. The responses were tape recorded so that they could be analysed at a later time. The specific questions of the questionnaire were based on the literature reviewed and the identified problems. The questionnaire comprised of a total of 47 questions and was developed and based on categories such as the qualification of respondent and family business; structure of the family business and relationships; brief history of the family business; training and development of successor; succession process; and management and policies. However, findings related to the last 5 sections are herein presented for the sake of brevity.

\section{RESULTS AND DISCUSION}

All the six respondents agreed that FF started the FB as he has always wanted to start his own business. When moving in with FM's mother, the opportunity presented itself as household expenses were reduced. The family members said SSE was given four months to travel overseas before returning to assist FF with the running of the FB. At the inception, $\square \mathrm{FM}$ assisted for six years in the evenings as the bookkeeper, before handing over to her sister; and SSE and SSS assisted FF with preparations of the first store, which was started in June 1995. The second and third store opened in 2001 and 2005 respectively.

When asked about information pertaining to the culture and values espoused by the $\mathrm{FB}$, all successors agreed that FF is a very hardworking founder who put a lot of hours into the FB to make it successful. They noted that $\square$ FF worked behind the counter personally in order to make sure that required service delivery standard was maintained. SST observed that there is a very open door, professional, yet relaxed culture in the firm. $\square$ For example, the successors encourage a monthly gathering of the employees for a braai; $\square$ drinks (alcohol and non-alcohol) were often consumed after work in a bid to provide an opportunity for the employees and the successors to communicate in a relaxed manner. In effect, friendliness and a feeling of family belonging amongst employees were encouraged by the successors. More so, FF stated that the employees comprised of their extended family members that include three brothers and four sisters.

According to Walsh (2011), family business succession comprises management succession and the ownership succession. Each requires involving family members so that at the end of the processes family members will have been involved and will feel comfortable making decisions about their individual and collective futures in the management and ownership of the family business. Through family communication links, the training and development of successors for desired outcomes can be assured. Family communication and other related activities should lead to the manifestation of integrated family unit after the succession 
period (Walsh, 2011). Thus, the findings of the case study are discussed based on succession related development, management and process issues in the next sections.

\section{Training and Development of Successors}

All respondents confirmed that there was a lot of "shop talk", especially around the dining room table and at family gatherings when they were growing up to the extent that FM often had to control the amount of "shop-talk" discussed around the table. The daily turnover and profitability of the business were openly discussed by FF. All respondents recalled that the "shop-talk" was of a positive nature and it encouraged the involvement of the siblings in the business. In order to get the siblings involved in the enterprise, FF would however have to resolve conflicts among family members who are in the business, formulate a succession plan and developing a strategic business plan that should incorporate a retirement and estate plan (Walsh, 2011).

SSS recalls that he could tell whether the day had been a good or poor one by the expression on FF's face when he returned home after work. In fact SST stated that he learnt many of the part codes by just listening to dinner table "shop-talk". However, the 'shop-talks' were not intentionally done rather they often occur due to the fact that FF and FM worked hard in the FB. In any case, both FF and FM usually speak positively about the FB during such talks. All the successors agreed that FF had a lot of pride in the firm since the family name was at stake. The siblings all felt that for the most part, the parents spoke positively about the business with pride. It was also mentioned that FF and FM stopped giving the siblings pocket money in order to earn money as they work part time at the FB. FM recalls that FF ensured that the siblings earned the minimum wage rate when they began to work in the firm. FF equally ensured that the successors worked at all levels of the FB and were not given any preferential treatment. This help build relationships with the other employees. FF also ensured that the successors were treated the same as other employees, in that if they wanted to work, they had to work every weekend regardless of other commitments.

The siblings were then asked to discuss any part time or holiday work that they did at the firm. In their view, the part time work was structured as FF ensured that the successors gained experience in all facets of the business. At one time or the other, each successor was a driver or spares store man, and also worked at the sales counter or in the procurement and administration departments. FF ensured that the successors started at the bottom of the business and worked their way up to management positions. All the successors were encouraged to work in the FB during school holidays and over weekends. FF insisted that if the successors wanted to work during school holidays; they had to commit to all of the days. All successors agreed that the wages they received were market related and would have been the same as if FF had employed someone else. For instance, SSE and SST were both fired by FF from their positions during the succession process in the past. Before re-joining the business, they were required to re-apply for their positions through an interview process. FF recalls that SSS was very nearly fired from his position too. However, it is notable that none of the successors gained significant work experience outside the FB. While SSE and SST had small informal work while travelling overseas, SSS only did community service for one year as a clinical psychologist before joining the firm.

In terms of formal education, S did not study any further after leaving secondary school; SSE studied a bachelor of commerce, but did not complete the final year due to work related pressures; $\square$ SSS has achieved a master's degree in clinical psychology; and SST studied bachelor of commerce, but did not complete the final year before he joined the firm. These suggest that tertiary education may not have played significant roles in the development of all the successors.

\section{Family Business Succession Process}

All the respondents agreed that FF initiated the succession process in the firm. FF always had the intention of SSE taking over the business as he had documents showing SSE's later 
succession in the business drawn up. When in 2002 at the age of 53, FF had a heart attack, FM then realised a need to accelerate the succession process. FM therefore encouraged SSS and SST to join the firm. FM realised that SSE's strength lies in his procurement and marketing abilities and not in financial matters. FM perceived that for the survival of the business, SSS should be encouraged so as to create a stronger business team. Perhaps, if not for the 2002 heart attack, FF contends that he would still be working in the business.

When asked to discuss the incumbent's attitude towards children succeeding parents. FF revealed that he was initially very nervous that the successors would not have the ability to succeed at running the firm. FF also perceived that the successors would not have the same amount of pride when running the business. So he made it very clear that if the successors were not running the business properly he would sell it. In order to show that he was serious; FF then withheld ownership of the business for 3 years during the succession process. He only relented when he became comfortable with the idea that the successors could manage the business.

Initially FF intended for SSE to take over the business as the other male siblings were not interested. After FF's heart attack in 2002, SSS and SST were given the opportunity to also join the FB, while $\square$ FF monitored the progress of succession from his office at home. Three years into the succession process, FF began the process of transferring ownership to the successors. SSS was instrumental in creating a family trust with each trustee owning $25 \%$ of the shares as indicated in Table 1. SSS assisted by appointing an attorney to compile a family trust and to create a "roles and responsibilities" constitution. Each successor raised finance that was used to purchase $25 \%$ of the newly formed trust. Each successor now manages and is responsible for one store. The time between initiating the succession to leadership takeover by the successors took approximately two years. SST recounted that S showed no interest in becoming a successor in the business.

In addition, the respondents were then asked to discuss conflicts during the process. It came out that during the succession process, SSE felt that equal shareholding between the successors was very unfair to him given the fact that he had worked in the business since its inception. All the successors opined that the conflict concerning the shares that lasted for approximately one year, was a "make or break" for the business. However, FM and SSS were instrumental in convincing SSE to realise that it would only be fair and in the best interests of the business if each successor controlled an equal share and earned equal salaries. As compensation for SSE's longer service to the FB, SSE was initially given a greater profit share. However, by the year 2011, all successors had an equal share of the profits. Giving everyone a chance to have their say and express their thoughts and feelings, privately and repeatedly as well as a considerate listening ability would have assisted in preventing the escalation of the conflict (Thompson, 2006).

During the succession process, FF and FM gave most of the coaching and mentoring to the successors. The successors often had to work under supervisors while they were learning the business. SSE and SST recalled that the development / leadership style of FF was to lead by example. Tacit and explicit knowledge were obtained by the successors by observing FF. FF recalls warding off many ideas SSE had by stating that when he succeeded the business, he could implement them. SSE observed that FF's desire to do things right made FF a good role model. FF's coaching concentrated more on the "the bigger picture" areas that entail how to succeed in business, ethics, morals, people skills and critical success factors. Such critical success factors for the FB include good customer service; $\square$ care of staff; correct stock holding; monitoring cash flow; honesty and integrity; and stock range.

The respondents were also asked to comment on the satisfaction levels of other stakeholders after the succession process was concluded. In responding, SSS noted that bankers were not too concerned as long as loans were paid timely. FM states that the banks were very impressed with SSS's conservative approach to finance and were more than 
eager to offer funding. FF perceives that SSE is very well respected by the part suppliers. He adds that SST is well thought of as a public relations person. When attending national franchisee gatherings, both FF and FM are proud that at all three successors are well respected by their peers. SSS and SSE opined that working alongside employees created strong employee relationships and ensured their buying-in after the succession. In the FB, all the successors created a second tier of management structure when they succeeded FF. New managers were appointed from existing employees with improved packages. It was apparent from the responses that common mistakes that plague family successions were less evident during the succession process in the case study. Thompson (2006) contends that not preparing yourself, not preparing your successor, not preparing the business, not really giving up control, hanging on too long, not securing your retirement money, not including your successors in the planning process and not doing a commercially sensible deal could derail the trajectory of a succession process. Therefore, making sure these mistakes do not occur is important for a successful outcome. There is also a need to commit to having an open, transparent and written succession plan that embrace a safe, open and objective process to uncover all the issues in the process (Thompson, 2006).

In spite of the conclusion of the succession period, all the respondents agreed that the FF attends quarterly meetings and other management meetings as a consultant. FF attends a minimum of four FB meetings to give advice to the management of the business. FM adds that all the successors have a great respect for FF business skills and they would all walk away from a business deal if FF did not think it was viable. This reported family cohesion is elaborated upon by Stenholm (2010) who says in a family company, the most successful leadership transitions occur when the board, family council and management regularly work together to develop chief executive criteria that is closely aligned to the organization's strategic objectives while ensuring that likely internal candidates are benchmarked against the best-in-class and address any skill gaps. It is good business practice for family companies to position themselves for the future by investing in robust leadership development and succession planning processes that adapt succession planning best practices to the unique characteristics of family-owned businesses (Stenholm, 2010).

\section{Management and Policies}

Each successor has an equal share in the business and controls one of the three stores in Port Elizabeth. There is no CEO in place in the business. Decisions are made on a "one trustee, one vote basis", in the event of a split decision; the majority of votes would be accepted. However, it was noted that SSS by virtue of his communication and conflict resolution abilities has a tendency towards overall leadership and control. Therefore, he often acts as the chairman in meetings. In this context, all the successors are currently performing manager-builder roles in the form. The successors have plans to expand the business, both within the franchise group and into different industries. SSE has the most entrepreneurial tendencies out of all of the successors. SSS also was of the opinion that the residential growth in Port Elizabeth is occurring in the areas where their stores are located. This offers opportunities for increased sales for their business. However, FF feels that the FB should not be allowed to grow too quickly as this could put pressure on cash flow in the firm. The respondents further contend that the successors perceived that most of the major business challenges for the current FB structure have been addressed by them.

Concerning constitution or set of rules that are governing the firm, a "beneficiaries' agreement" was signed by all the successors and FF regarding the ownership of the company and variations thereof. A "list of functions" was also signed by each successor. The list indicates the responsibilities that each successor must perform. Nevertheless, the respondents noted that issues are openly discussed (often informally) or at a meeting between the successors and with regard to larger decisions FF is always consulted. As SSS controls the administration and finance, he often has the final say before a decision is made; advising whether the business can afford to undertake a project or not. The "one trustee, one 
vote" has not been applicable thus far since consensus is often reached between the trustees before going to vote. As mentioned, if FF does not like a business transaction all the successors would walk away from the deal.

All the respondents agreed that pride, integrity, honesty and fairness to employees are very important in the firm. The respondents were of the opinion that equity between successors, pride and the family name associated with the business, trust and harmonious / close family relationships, among others, are the main reasons for the success of the FB. In this sense, FM is instrumental in maintaining and promoting good family relationships in the firm. All the successors further mentioned that they are very proud of the FB and perceive that their name is synonymous with the success of the FB. Even FF contends that he would "love" to see the third generation participate in the business. FF recounted that while driving with the successors to a business trip recently, the successors were beginning to talk about how and what would be required to have the third generation succeed them. However, only SSS has a nine month old son and has not given much consideration to his son succeeding him at the time of the interview. SSE and SST do not have children yet and have not given much consideration to future children succeeding them. Against the backdrop of the view that majority of owner managers intend to pass the business on to their children, but less than $30 \%$ have a succession plan and the perception that only $30 \%$ of owner-managed businesses are passed on to the first generation, and that only $10 \%$ make it to the third (Thompson, 2006), the long term succession planning that is mentioned in the studied case is a step in the right direction.

\section{FUTURE RESEARCH}

Prior to the implementation of the succession plan, the successors to this case study faced an ownership dilemma. SSE perceived that equal shareholding offered to his brothers was unfair given the amount of time he had worked for the firm prior to their involvement and that the other successor had previously shown no interest in the business. The negotiation skills of SSS when drafting the "beneficiaries' agreement" and the conflict management skills of FM were crucial for the success of the succession. All successors now agree that without equal ownership of the business, the business would not survive. Thus, future research may look at the importance of equal ownership and earnings between successors for the survival of such businesses.

\section{CONCLUSIONS}

As family businesses continue to dominate the economic landscape, it is argued that this study contributes to the debate regarding the success rate of successions to some extent. Of particular significance regarding this case study was the importance of resolving the ownership conflict between the successors during the succession process. All the respondents viewed the resolution of this conflict as paramount to the success of the succession. The successors all opined that equal ownership remains crucial to the harmony between the successors and thus the continuance of the business.

Concerning the six prepositions proposed by Cater and Justis (2009), certain inferences can be made based on the findings of the case study. All the respondents agreed that trust among the family members was essential to the positive outcome of the succession process. This is in agreement with the first preposition. Although SSE was chosen to succeed FF from the onset of the business, the inclusion of SSS and SST by FM showed a willingness to have all siblings succeed in the business. The structured approach by FF regarding successors' ability to acquire knowledge of the business supports the long-term orientation of FF to have the business succeeded by the siblings. FM played an important role in managing the conflict between the siblings during the succession process, displaying a desire to have a smooth succession transfer. All the successors share a deep sense of 
pride associated with the family name, a situation that contributes to the display of a strong sense of leadership continuity. The above arguments thus support the preposition that a long term orientation that promotes succession existed in this case.

Although the successors were very competitive when growing up and rivalry existed among them, their relationships were and remain very cordial. The eventual realisation by SSE that equal ownership should exist, together with the negotiations between the other successors show their willingness to cooperate. All the successors are satisfied with the "one trustee, vote" concept, which lays a foundation for future conflict resolution and decision making between the successors. The willingness of the family members to get together regularly suggests that they favour the spirit of togetherness. The structured staggered approach to profit sharing and ownership distribution ensured a fair method of compensation to the successors. Thus, the willingness of the successors to resolve and negotiate a fair integration to succession shows they have a positive spirit towards cooperation.

In addition, FF ensured that the successors had a "hands on" approach when working parttime and when joining the family business. This also meant that employees accepted the successors from the onset of the succession process. The successors were required to work under supervisors or were mentored by FF. 'Shop talk' also provided the successors with knowledge about the industry and other stakeholders. The aforesaid supports the preposition that the successors acquired rapid knowledge of the industry.

All the successors are looking to expand the business using the inherited business foundation as a platform. These observations support the preposition that the successors have adopted a manager-builder type role in the business. The findings of this case show that the successors are ambitious and willing to take calculated risks with expansion efforts. This supports the findings of Cater and Justis (2009) that successors typically perceive themselves to be more risk orientated than predecessors.

\section{REFERENCES}

Barney, J.B. Clark, C. \& Alvarez, S. (2002) Where does entrepreneurship come from: Network models of opportunity recognition and resource acquisition with application to the family firm? In: Proceedings of the Second Annual Conference on Theories of the Family Enterprise. Philadelphia: University of Pennsylvania.

Bertrand, M. \& Schoar, A. (2006) The role of family in family firms. Journal of Economic Perspectives, 20 (2), pp. 73-96

Bigliardi, B. \& Dormio, A.I. (2009) Successful generational change in family business. Measuring Business Excellence, 13(2), pp. 44-50.

Cater, J.J. \& Justis, R.T. (2009) The development of successors from followers to leaders in small family firms: An Exploratory Study. Family Business Review, 22 (2), pp. 109-124.

Chrisman, J.J., Chua, J.H. \& Sharma, P. (2003) Current trends and future directions in family business management studies: Toward a theory of the family firm. Coleman White Paper Series.

Chua, J.H., Chrisman, J.J. \& Sharma, P. (1999) Defining the family business by behavior. Entrepreneurship Theory and Practice, 23(4), pp. 19-39.

Colli. A. (2003) The history of family business 1850-2000. Cambridge, UK: Cambridge university press.

Cullen, M. (2005) The development of an entrepreneurial model to promote the survival and growth of family estate wine businesses in the South African wine industry. PhD Thesis. Nelson Mandela Metropolitan University. 
Daniell, M.A. (2008) Strategy for the wealthy family: seven principles to assure riches to riches across generations. New Jersey: John Wiley \& sons.

Farrington, S.M. (2009) Sibling partnerships in South African small and mediumsized family businesses, PhD Thesis. Nelson Mandela Metropolitan University.

Grant, R.M. (2007) Contemporary Strategy Analysis: Concepts, Techniques, Applications. $6^{\text {th }}$ ed. Oxford: Wiley-Blackwell.

Javitch, D.G. (2005) Successful Succession Planning. [Online] Available from: http://www.entrepreneur.com/humanresources/employeemanagement

columnistdavidjavitch/article77974.html

[Accessed 1 March 2010]

Landes, D.S. (2006) Dynasties. Fortunes and Misfortunes of the world's great family businesses, Boston: Penguin (non-classics).

Poutziouris, P.Z., Smyrnios, K.X., \& Klein, S.B. (2006) Handbook of Research on Family Business. Cheltenham: Edward Elgar.

Santiago, A.L. (2000) Succession experiences in Philippine family businesses. Family Business Review, 13(1), pp. 15-40.

Schulze, W. S., Lubatkin, M. H. \& Dino, R. N. (2003) Toward a Theory of Agency and Altruism in Family Firms. Journal of Business Venturing, 18(4), pp. 473-490.

Schwass, J. (2008) Dealing with the complexity of Family Business: strategies for long-term success. [Online]. Available from: http://www.imd.ch/research/challenges/upload/TC025_08_dealing_with_complexitiy_of_famil y_business.pdf [Accessed 28 April 2010]

Stenholm, G. (2010) Beyond the family tree: succession planning for family business [Online]. Available from:

http://content.spencerstuart.com/sswebsite/pdf/lib/famBus 0310.pdf $\quad$ [Accessed 7 July 2013]

Thompson, P. (2006) Succession planning and the family business [Online]. Available from:

http://www.thompsonlaw.ca/pdf folder/Succession Plans FB 06.pdf

[Accessed 7 July 2013]

Venter E. \& Boshoff C. (2007) The influence of organisational-related factors on the succession process in small and medium sized family businesses. Management Dynamics, 16(1), pp. 42-55.

Walsh, G. (2011) Family business succession: managing the all-important family component. Ottawa: KPMG Enterprise.

Yin, K.R. (2003) Case study research design and methods. 2nd edition. California, USA: Sage Publications. 